\title{
GEOMETRIE KVARCITOVÝCH TĚLES V OKOLÍ PŘíCHOVIC
}

\section{Geometry of quartzite bodies from Príchovice surroundings}

\author{
Michal Uhlír, Rostislav Melichar \\ Ústav geologických věd, Prírodovědecká fakulta, Masarykova univerzita, Kotlářská 267/2, 61137 Brno; \\ e-mail:lion007@seznam.cz;melda@sci.muni.cz
}

(03-14 Liberec, 03-23 Harrachov)

Key words: Lugicum, Krkonoše-Jizera Crystalline Unit, quartzite, fold, structural analysis

\begin{abstract}
Quarzite as a metasedimentary rock is usually figured in prolongated bands in geological maps. But muscovite quartzite from Krkonoše-Jizera Crystalline Unit in SE surrounding of Př́chovice village forms irregular shapes in detailed geological maps (e.g.,Mrázová - Štěpánek 2007, see Fig. 1), which do not allow simple interpretation of the geometry of quartzite bodies. To find correct $3 D$ geometry of the bodies, we used standard methods of detailed mapping and documentation of outcrops as well as detailed structural analysis. Locations of terrain edges with quartzite outcrops have been indicated in the map (Fig. $3-A, B, C$ ). Generaly sub-horizontal to moderately dipping metamorphic foliation has been found. Foliation poles make wide girdle in the plot (Fig. 2) which indicates sub-cylindrical fold structure with horizontal axis in the NW-SE direction.

Studied area can be geomorphologically divided into two different parts. The northeastern part of the territory is sub-horizontal plateau, while the southwestern part is generally inclined to the southwest. In the second part, the metamorphic foliation dips to the southwest under such angle, that it seems to be parallel to the inclination of the slope, see the old quarry (Fig. 3B) and SW part of Velká bílá skála (Fig. 3A). The last one show us bent outcrop respecting the change in slope inclination. Large shear bands were directly observed as a part of S-C structure. It indicates that SW limb of the fold was strained under simple shear condition with the drop SW kinematics (Fig. 4). Change in orientation of SW-dipping fold limb was produced by a ductile shear zone.

Based on a combination of metamorphic foliation orientation of quartzite and field edges, we can interpret quartzite rocks as a part of one platy body, which forms the overall morphology of the landscape south of Prichovice. In the plateau, erosion stopped at subhorizontally oriented part of the quartzite layer, while denudation of the SW limb of the large fold predeterminates the inclined slope surface to the $S W$ (Fig. 3D). Relics of thin overlying rocks remaining on quartzite in some places and erosion of the small creeks produce bizarre forms in geological map, which seems to be difficult to understand. This study has shown that such complex structure can be decrypted using the detailed structural analysis. In this case it was shown that quartzite forms a relatively simple body which was only slightly bent due to simple shear deformation.
\end{abstract}

\section{Úvod}

Při zpracovávání stavby krkonošsko-jizerského krystalinika v jv. okolí Př́ichovic na podzim roku 2015 byly studovány kvarcitové polohy a geometrie jejich stavby. Zájmová oblast leží v západosudetské části lugika, a to v krkonošsko-jizerském krystaliniku. Podrobný strukturně geologický průzkum tohoto území začal až po 2. světové válce. Kodym a Svoboda (1948) vytvořili představu př́ikrovové stavby krkonošsko-jizerského krystalinika. Kvarcitová tělesa podle nich tvoří vložky $\mathrm{v}$ tektonicky velmi komplikovaném pruhu. Drobnou tektonikou se ve studovaném území zabýval Máška (1954), který prokázal jednotnou vnitřní stavbu údajných př́ikrovových těles. Chaloupský (1989a) sestavil geologickou mapu v měŕítku 1 : 50000 (obr. 1B). V zájmové oblasti vymezil stratigrafické jednotky (velkoúpskou a ponikelskou skupinu) s rozdílným stárím a přehledně shrnul starší výzkumy (Chaloupský 1989b). Později Kachlík (1997) doložil, že se jedná o jednotný staropaleozoický komplex. Nejnovější mapování prováděli Mrázová - Štěpánek (2007), kteří $\mathrm{v}$ mapě vymezili i kvarcitová tělesa (obr. 1A).

Kvarcity jsou obvykle metasedimenty tvořené z převážné části křemenem. Převážně muskovitické kvarcity vystupující ve studovaném území tvoří mohutné výchozy s výškou až $13 \mathrm{~m}$ (např. Bílá skála). Okolní měkčí horniny jsou zastoupeny různými typy svorů a fylitů s nehojnými vložkami erlanů (Chaloupský 1989b) a jsou téměř bez výchozů. V geologických mapách se kvarcity standardně zobrazují jako více či méně průběžné pruhy, srov. např̀. Svoboda et al. (1947), což implikuje jejich deskovitou
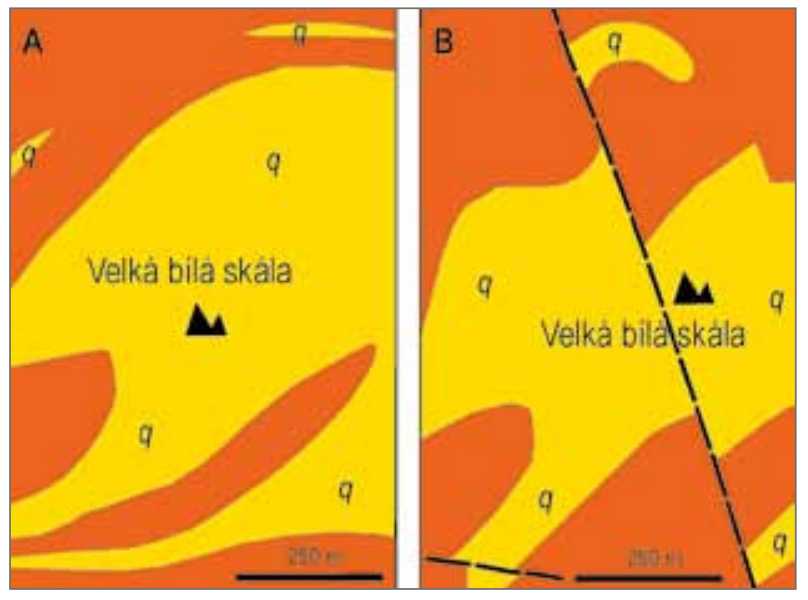

Obr. 1: Nepravidelné tvary kvarcitových těles $(q)$ v podrobných geologických mapách: A - v mapě $1: 25000$ (Mrázová - Štěpánek 2007); B - v mapě 1 : 50000 (Chaloupský 1989a); okolí Velké bílé skály jv. od Př́íchovic v krkonošsko-jizerském krystaliniku. Fig. 1: Irregular forms of quartzite bodies $(q)$ in detailed geological maps: A -in the map 1:25 000 (Mrázová -Štěpánek 2007), B - in the map 1: 50000 (Chaloupský 1989a); surroundings of the Velká bílá skála SE of Př́chovice in the Krkonoše-Jizera Crystalline Unit. 


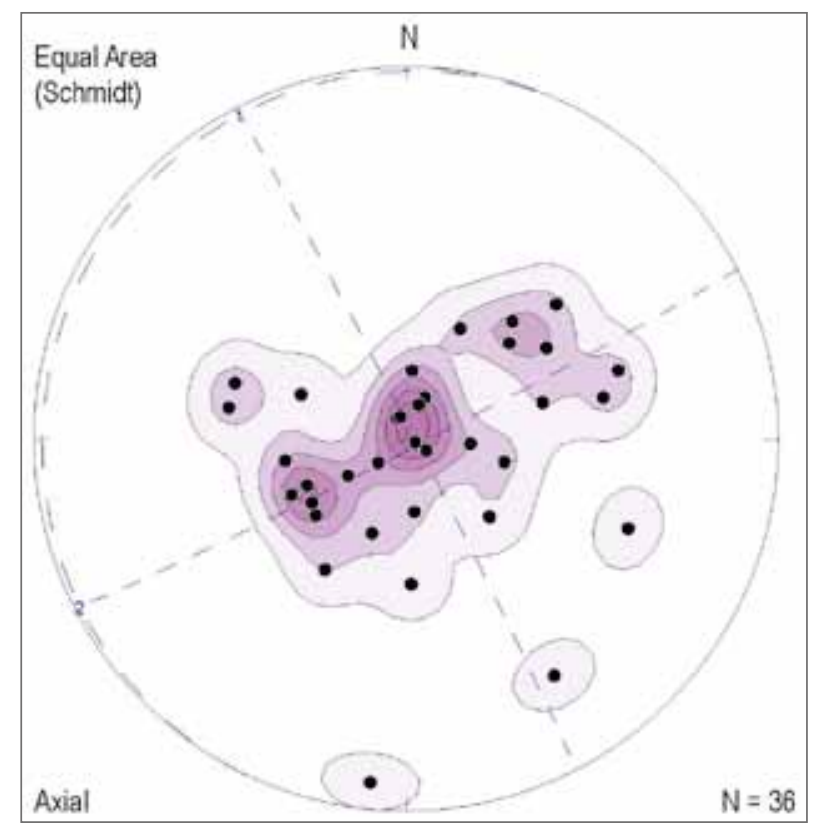

Obr. 2: Konturový diagram pólů ploch metamorfních foliací kvarcitů z krkonošsko-jizerského krystalinika jv. od Př́chovic. Čárkované oblouky vyznačují hlavní roviny a jejich průsečíky hlavní osy matice orientace.

Fig. 2: The contoured plot of poles of metamorphic foliation surfaces of quartzite rocks from the Krkonoše-Jizera Crystalline Unit SE of Př́chovice. Dashed great circles are principal planes and their intersections are principal axes of orientation matrix.

geologickým kompasem Freiberg, naměřené hodnoty byly zpracovány v programu Spheristat za použití azimutální Lambertovy rovnoploché projekce na spodní polokouli. Osa velké vrásové stavby a orientace průměrné foliace byla určena pomocí matice orientace, jejíž charakteristické vektory byly vypočteny v programu Spheristat.

\section{Výsledky}

Naměřené orientace metamorfních foliací jsou převážně subhorizontální až mírně ukloněné. Průměrná

geometrii. Kvarcity z východního okolí Příchovic však byly v podrobných geologických mapách (Chaloupský 1989a; Mrázová - Štěpá nek 2007) zobrazeny v podobě různých nepravidelných tvarů (obr. 1), které neumožňují jednoduchou interpretaci geometrie kvarcitových těles.

\section{Metodika}

K nalezení správné geometrie zájmových těles byla užita standardní metodika podrobného mapování a dokumentace výchozů doplněná strukturně geologickým měřením orientace strukturních prvků. Byly sledovány horninové výchozy kvarcitů a výskyt a tvar morfologicky výrazných terénních hran vyztužených kvarcity a jejich průběh byl zakreslován do mapy. Měření orientace foliací bylo prováděno

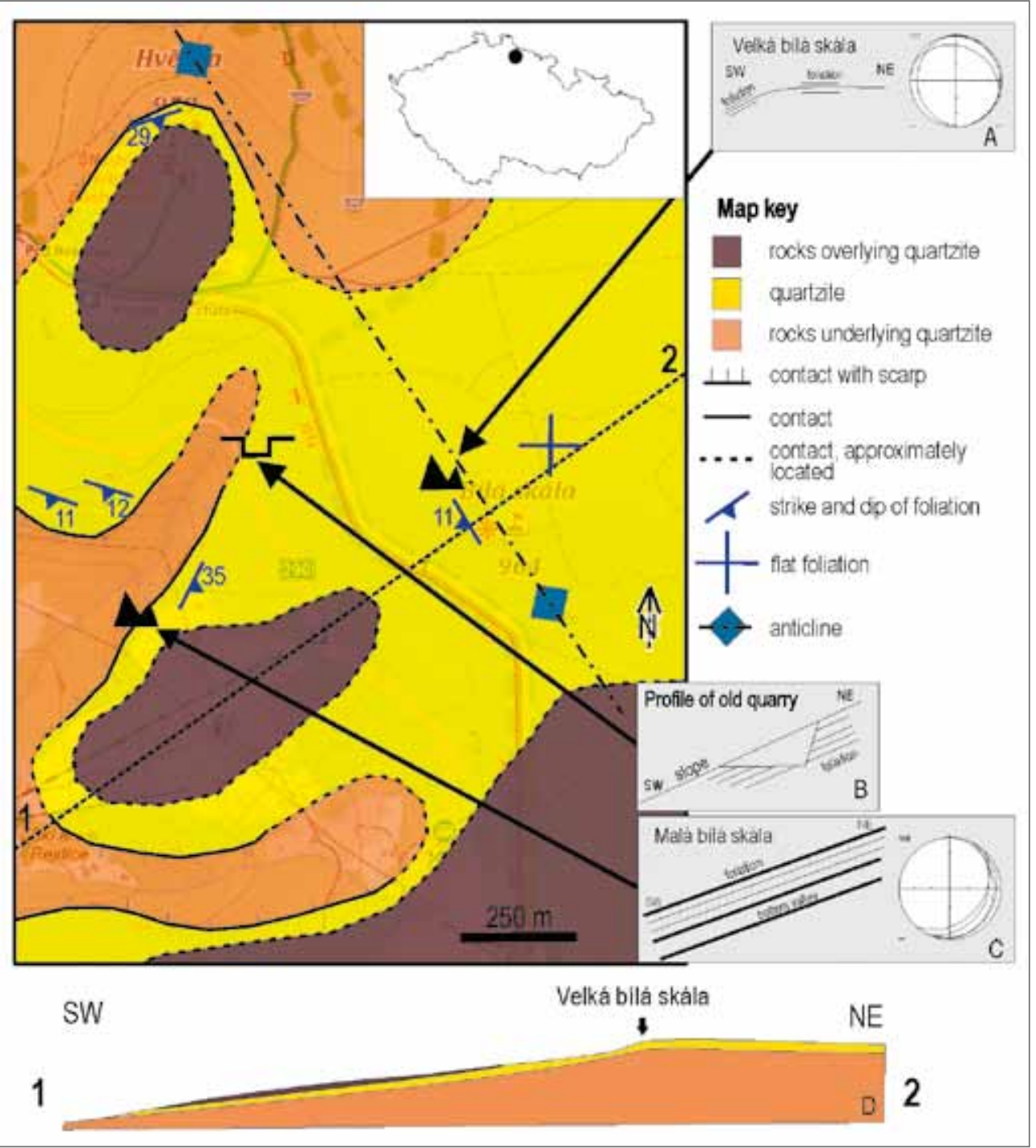

Obr. 3: Zjednodušená geologická mapa a geologický řez části krkonošsko-jizerského krystalinika jv. od Příchovic. Klíčové lokality (A, B a C) zobrazují vztah metamorfních foliací a morfologie terénu. Fig. 3: Simplified geological map and geological cross section of the Krkonoše-Jizera Crystalline Unit, SE of Př́chovice. Key localities (A, B and C) show relationship of the metamorphic foliation and terrain morphology. 
orientace foliací je S 271/01 (obr. 2). V diagramu na obrázku 2 jsou póly foliací uskupeny do neostrého pásu, který naznačuje nevýraznou cylindrickou vrásovou stavbu s horizontální osou směru SZ-JV (F 326/01).

Pro řešení geometrie stavby bylo důležité studium geomorfologie a její kombinace s geologickými údaji. Geomorfologicky lze studované území rozdělit na dvě odlišné části. V severovýchodní polovině území se jedná o téměř horizontální „náhorní “ rovinu, zatímco v části jz. je terén tvořen rozbrázděným svahem s generálním sklonem k jihozápadu. Výsledky plošného průzkumu stavby kvarcitových těles v daném území lze dobře demonstrovat na struktuře tř́i klíčových lokalit, kterými jsou: starýlom u silnice, Malá bílá skála a Velká bílá skála.

Na klíčových lokalitách starého lomu a jz. části Velké bílé skály (obr. 3A, 3B) jsou naměřené orientace metamorfních foliací převážně ukloněné $\mathrm{k}$ jz. rovnoběžně s celkovým průběhem svahu. $\mathrm{V}$ celé jz. části terénu v okolí uvedených dvou klíčových lokalit je patrný průběh výchozů paralelně s celkovým sklonem svahu, což je velmi dobře pozorovatelné především v drobných údolích prořezávajících hlavní svah. Ve studovaném území tak bylo zjištěno, že průběh metamorfní foliace kvarcitů je paralelní s průběhem kvarcitových těles a jejich výchozů.

Na klíčové lokalitě Velká bílá skála (obr. 3A) byl př́mo pozorován ohyb tvaru výchozu, který respektuje změnu sklonu svahu, a vznik novotvořených foliací souběžných $s$ průběhem výchozu. $\mathrm{V}$ krrídle ukloněném k JZ byly pozorovány střrižné pásy, které jsou součástí hrubé S-C struktury (ve smyslu Passchiera - Trouwa 1996, p. 122). Jejich př́tomnost dokládá intenzivní deformaci tohoto kř́idla mechanismem jednoduchého střihu s poklesovou kinematikou (obr. 4).

\section{Diskuze a závěr}

Na základě kombinace orientace metamorfních foliací kvarcitů a terénních hran vyztužených kvarcitickými horninami lze usuzovat, že výchozy kvarcitů nalezené v terénu jsou součástí v podstatě jednoho deskovitého tělesa, které zároveň „drží“ celkovou morfologii krajiny jv. od Př́chovic. Z geometrie pásu lze odhadovat, že se na stavbě území podílí bud’ široce rozevřená víceméně přímá vrása nebo silně sevřená, prakticky ležatá vrása. V místech náhorní plošiny se eroze zastavila na úrovni subhorizontálně orientované polohy kvarcitu, zatímco v jz. části území ukloněná část desky vyztužuje svah

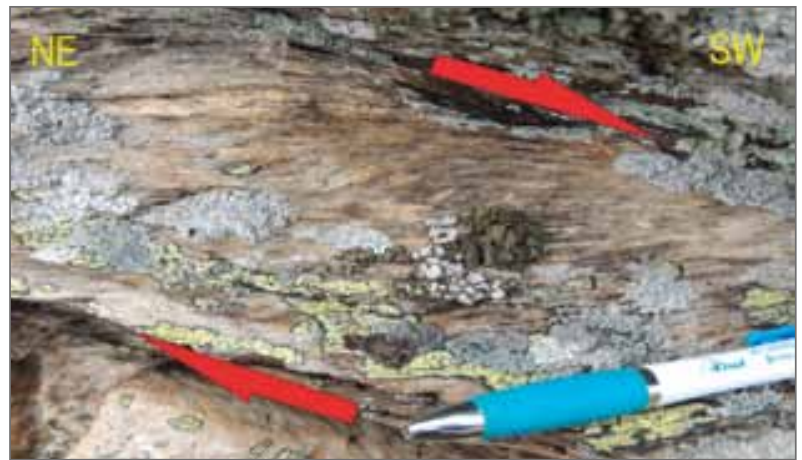

Obr. 4: Červené šipky jsou lokalizovány do míst střižných pásů - C-střihů hrubé S-C struktury v kvarcitech z lokality Velká bílá skála a ukazují deformaci jednoduchým střihem kvarcitu s poklesovým charakterem ve směru SV-JZ.

Fig. 4: Red arrows are situated in place of shear bands, which are equal to $\mathrm{C}$ shear bands of large $\mathrm{S}-\mathrm{C}$ structure in quartzite from the locality Velká bílá skála, and show simple shearing with top-to-the SW movement.

ukloněný kjihozápadu. Celkový průběh tělesa je zobrazen v řezu (obr. 3D). Na lokalitě Velká bílá skála je toto těleso ohnuto a tvoří vrásu. Ohyb byl způsoben poklesovou duktilní střrižnou zónou, kdy nadložní horninový komplex je po deformaci ukloněn $\mathrm{k}$ JZ. Existenci duktilní stř̌ižné zóny dokládá vedle stočení průběhu kvarcitového tělesa zejména prítomnost znaků deformace jednoduchým střihem (viz zmíněné S-C struktury, obr. 4).

Poměrně ploché uložení a odolnost kvarcitů při zvětrávání a erozi vedly $\mathrm{k}$ tomu, že kvarcitové těleso tvoří podpovrchovou polohu erozivně formované krajiny. Na některých místech zůstaly na kvarcitech tenké relikty nadložních hornin (obr. 3).

Pozdější oživení a zpětná eroze malými toky vedly $\mathrm{k}$ tomu, že toto těleso bylo rozbrázděno malými údolími na lalokovité nepravidelné výběžky, které zdánlivě nezapadají do geologické stavby dříve publikovaných výsledků (Chaloupský 1989a; Mrázová - Štěpánek 2007). Provedená studie však ukázala, že i vymapované nepravidelné až amébovité tvary (obr. 1) mohou být dešifrovány s použitím detailní strukturní analýzy. $\mathrm{V}$ tomto př́padě se ukázalo, že kvarcit tvoří poměrně jednoduché těleso, jehož část byla $\mathrm{v}$ rámci střižné zóny mírně přetočena ukloněna následkem deformace jednoduchým střihem. Znalost přesné geometrie umožnila oproti starším mapám odlišit nadložní a podložní komplexy hornin. 


\section{Literatura}

Chaloupský, J. (1989a): Geologická mapa ČSR. List 03-23 Harrachov. - Ústřední ústav geologický. Praha.

Chaloupský, J. (1989b): Geologie Krkonoš a Jizerských hor. - Academia. Praha.

Kachlík, V. (1997): Litostratigrafie a stavba železnobrodského krystalinika: výsledek variských tektodeformačních procesů. Zprávy o geologických výzkumech v roce 1996, 30, 30-31. Praha.

Kodym, O. - Svoboda, J. (1948): Kaledonská př́ikrovová stavba Krkonoš a Jizerských hor. - Státního geologického ústavu Československé republiky, 15, 109-180. Praha.

Máška, M. (1954): K tektonické analýze krystalinika. - Knihovna Ústředního ústavu geologického, 27, 1-259. Nakladatelství Československé akademie věd. Praha.

Mrázová, Š. - Štěpánek, P. (2007): Geologická mapa $1: 25$ 000, list Harrachov 03-233. - MS, Ústřední ústav geologický. Praha. On-line: http://mapy.geology.cz/geocr_25/

Passchier, C. W. - Trouw, R. A. (1996). Microtectonics. - Springer. Berlin.

Svoboda, J. - Kodym, O. - Prokop, F. (1947): Přehledná geologická mapa Krkonoš a Jizerských hor. - In: Máška, M. (1954): K tektonické analýze krystalinika. Nakladatelství Československé akademie věd. Praha. 